\title{
Biopolitics: Slavery, Racism and Eugenics in Latin America
}

\author{
Maria Cristina Gomes da Conceicao
}

Latin American Faculty of Social Sciences, FLACSO Mexico, Mexico

\section{ARTICLE INFO}

Keywords:

Slavery

Racism

Eugenics

Biopolitics

Latin America

\begin{abstract}
This article analyzes historical population changes as mechanisms of biopower in Latin America: during colonization, the crisis of indigenous groups, the arrival of enslaved Africans and, later, the immigration of free settler Europeans to replace both indigenous people and Africans as workforce and land property. The perspectives of settler colonialism and biopower are adopted to understand how sequential mechanisms of biopolitics were implemented in settler societies, through genocide and the assimilation of the majority, who were progressively being eliminated or transformed into minorities. The method includes literature review of the predominant concepts, discourses and practices established in the biopolitical process attached to settler colonialism, as well as the methods, institutions, policies and actors who built these modes of biopower. The results show the adoption of several biopolitics mechanisms, such as wars, epidemics, over-exploitation, land confiscation, the kidnaping of women, inferiorization, human trafficking and cruel punishments, during colonialism, as well as miscegenation, isolation and the marginalization and disappearing of those resisting in the transition to settler colonialism, when eugenic policies of fertility control and European immigration were implemented in order to whiten the population, which reinforced, articulated and validated the persistent racism, discrimination against and disadvantages forced upon these populations.
\end{abstract}

\section{Introduction}

Discrimination, social inequalities and racism today are treated as a problem of blacks, indigenous people, gypsies, the disabled, women, LGBT groups, sex workers, the poor, and immigrants. However, discrimination and racism are built on human interactions, and on unequal power relations between individuals and societies. They are historical constructs of beliefs, values, ideologies, policies, institutions, attitudes and practices reproduced from the different positions assumed by social groups with unequal powers, rights and privileges and which, precisely because of these differences, establish the systematic favoring of certain people and groups, and the exclusion of others (Brown, 1995; Vala \& Lopes, 1999). For centuries, modern slavery, racism and eugenics have been the biopower mechanisms that reproduce inequalities among human beings, through allowing some groups or populations to force other groups to work without rights and freedoms.

This article aims to analyze the persistent reproduction of inequalities in Latin America from a historical perspective. Since the conquests, and through four centuries of colonization, at least three phases of historical population changes occurred in Latin America - the crisis of indigenous groups, the arrival of enslaved Africans and, later, the arrival of free Europeans immigrants to replace both the indigenous and Africans, in the labor market.

\footnotetext{
* Corresponding Author E-Mail Address: cristinagomesmx@gmail.com 
In the beginning, European and United States colonialism distinguished between colony and metropole adopting modern slavery as the first mechanism of biopower. In the new independent nations, considered settler societies, the modern concepts of races, racism and eugenics were the new mechanisms of biopower to continue controlling the reproduction of indigenous and Africans and to promote European immigration to whiten populations. Biopolitical mechanisms continue operating up to the present day to effectively repress, co-opt and extinguish indigenous and African alterities, and to productively manage ethnic diversity (Mbembe, 2003, pp. 4).

\subsection{Conquest, Colonization, Indigenous Slavery and Population Crisis}

Slavery was universal in all the ancient regimes. From the classical empires of Greece and Rome to those of the Aztecs, Mongols and African kings, wars were common, and defeated enemies were enslaved and forced to work for their conquerors.

Between the 10th and 16th centuries AD, until the Middle Ages and the discovery of America, Western Europe used Eastern Europe as the main source of enslaved people. The word "Slav" comes from Slavs, or "people of Eastern Europe", the majority of slaved in Europe, who were considered "barbarians" due to their cultural differences. This ancient slavery was not based on the distinction of skin color as most of the slaved were white people, there was no record of prejudice against Africans or other groups due to their skin color, but ethnocentrism and cultural discrimination (Klein \& III, 2007).

Today, this ancient worldwide slavery is often omitted, as if it only occurred in ancient Africa. This distortion of the history of the slavery by Europeans and other ancient civilizations is used to justify the new regime of slavery that emerged in Modernity - the hunting of Africans by European traders, and their forced removal from their homelands to work in the New World. This effort aims to mitigate the role of Europe in the trafficking of Africans, assuming that it would be a pre-existing experience, legitimized and acceptable in ancient African societies.

This assumption denies the origin of modern slavery, characterized by human trafficking, and the inferiorization of some human beings - indigenous and African, due to their skin color and culture, in contrast to Europeans. Their sale as commodities, inhuman treatment was justified through the construction of the modern concept of races and racism in Modern Europe, and the international legitimation and dissemination of eugenics, while Europe was consolidating the values of equality, fraternity and liberty for all their citizens (Selfa, 2002).

Since the $14^{\text {th }}$ Century, the conquest and settler colonization of America adopted biopolitical strategies of war, slavery and over-exploitation of the indigenous peoples, resulting in massive reductions in their populations and even the extinction of some groups.

According to the censuses of tributaries and inspection visits of the Spanish government. Before the Conquest, the indigenous population of Hispanic America corresponded to 8-10 million and, 80 years after Colombus discovered America (50 years after the destruction of the Aztec capital and 40 years after the assassination of the Inca emperor), this population decreased to around 2 million. In a few decades, the Azteca population decreased from 2.7 to 1.4 million, the Inca population deceased from 1.3 to 0.9 million in 1600 . In most of Central America and all the Caribbean, indigenous people were exterminated (for example, about 1 million of Tainos were driven to extinction in 1550). The Gulf of Mexico and the coast of Peru were depopulated in the middle of the century, the inhabitants were killed or forced out by malaria or by the Conquered wars (Livi-Bacci, 2006).

A multicausal set of factors explains this population crisis: Biological components included epidemics of new diseases imported from Europe combined with biopolitical practices, including the destruction of previous indigenous infrastructures, deforestation and the new 
livestock being brought in from Europe. Biopolitical factors such as wars and the loss of freedom and autonomy had a severe effect, as did social components like the dislocation and rupture of communities, forced migration and miscegenation. Economic factors like changes in production patterns, the exploitation and confiscation of workers, lands and tributes played an important part, along with biopolitics components.

Friar Bartolomé de las Casas's Brief history of the destruction of the Indies. 1542-1552, emphasizes the cruelty of Spaniards and the horrific violence perpetrated by conquerors and encomenderos, as well as the cruel wars and hard servitude against men and animals, a version named "The Black Legend". As new laws were established in 1542 and the encomienda system changed, Spain rejects this version, and explains away the population crisis with epidemics, considering that in some decades, the diseases introduced by Europeans and subsequent contact between tribes would alone kill about $95 \%$ of the native American population, and it would became the exclusive reason to explain a decrease from the original Americas' population of 100 million to 5 million. However, epidemiologists consider it unlikely or impossible that chickenpox would disseminate in few decades across the continent, from Mexico to South America, with such a massive impact. Chickenpox epidemics would not be considered the main or the only culprit in the South American population catastrophe, particularly during the reign of Inca Emperor Huayan Capac, when there were thousands of tribute payers (Livi-Bacci, 2006).

According to this multifactor explanation, settler colonialism - the Black Legend played an important role in the indigenous catastrophe:

"It is true that there was a demographic collapse, disease is certainly a probable explanation (crises in 1546 and 1558), but also wars, devastations, famines and a myriad of causes are combined... After a quarter century of uninterrupted wars, the country was devastated and exhausted." Livi-Bacci (2006).

The epidemic was no less destructive than wars and over-exploitation. In the Caribbean, the violent conquest and the extinction of indigenous people was firstly due to chickenpox, but biopolitics also impacted them. (Livi-Bacci, 2006). Settler colonialism and correlated biopower strategies legitimized the murder of indigenous people through war and slavery, economic changes in production patterns, exploitation, the confiscation of forced work, lands and tributes, forced labor and migration to work in mines and construction, the destruction of communities and indigenous infrastructures, the kidnapping of women to breed with their conquerors and the separation of indigenous couples, families and communities, leading to escapes and suicides.

Colonialism and its biopower strategies increased mortality and weakened indigenous reproduction. That included the coast of Venezuela and the complete and rapid extermination of natives occurred within a few decades. In the Gulf of Mexico and the Pacific coast of Peru, the depopulation was faster than in Mesoamerica (Mexico and Guatemala), or in the high Andes, and has multiple explanations - the pathogenic burden in harsh environments negatively interacted with new diseases imported from Europe; the arrival of the mosquitos in Mexico spread malaria, and on the Pacific coast of Peru, in the valleys surrounded by mountains, in which the natives lived. In the same occupied areas, there were destructive efforts of European invasion, appropriation of the best lands and the irrigation systems, which deprived the indigenous people of resources for survival. (Livi-Bacci, 2006).

Emigration and high mortality with low reproduction rates resulted from the biopower instrumentalization and destruction of indigenous populations and their existence - their land, resources, families, relationships, ways of life and their very bodies - in what is defined from the settling colonialism perspective as "elimination through genocide and assimilation" (Scott, 2011; Veracini, 2011). Before that there was violent expulsion of natives, weakening their 
ability to survive and reproduce, as occurred in Brazil, where the Portuguese occupied the east coast. In the Guaraní Missions in Paraguay and Brazil, social change applied in accordance with Jesuit rules brought stability, monogamy, and, without contact with Europeans and Africans, reinforced community solidarity which minimized conflicts and promoted high reproduction rates.

Social disruption, over-exploitation, epidemic diseases and severe shortages in the indigenous labor force allowed the Europeans to establish settler colonialism, since the conquest and colonization of American lands demanded the elimination, control, and assimilation of the "enemy" - the millions of "indigenous savages" who inhabited the newly-discovered territory. However, at the same time, indigenous elimination ended up being an economic obstacle for the European development, which was highly dependent on the exploitation of American colonies, lands and populations (Darien, 1995; Selfa, 2002). From the first decades of the 14 Century, to supply the New World with labor force, since the first decades of the 14th Century, European kingdoms promoted the trafficking of enslaved Africans as an alternative that became also a highly profitable business mainly for Britain, Spain and Portugal (Klein \& III, 2007).

\subsection{The Arrival of Africans in Europe and America}

Even before the discovery of America, European-African relations were based on negotiations between leaders from both continents, with some free Africans living in Europe, while others were involuntarily settled in the Iberian Peninsula. In the context of the Crusades, in 1452, the Portuguese King was authorized by Pope Nicolas V to enslave the "Saracens, pagans and any other unbelievers" who resisted conversion to Catholicism. In particular, those living on the southern coast of Africa were considered the enemies of Christ and a modest slave trade existed on the western coast of Africa.

The Portuguese started a small volume of trading with some African tribes for slaves to work in factories and trading posts in urban areas alongside Jews, Arabs, and Christians. The AfroIberian population and their communities increased and achieved 50 percent habitation of several neighborhoods in Lisbon and Seville, which was known as the "New Babylon. "The African populations became so socially and politically important that in 1475 the Crown appointed Juan de Valladolid, its royal servant and mayoral, to represent Seville's Afro-Iberian community. Churches and charities catered to its spiritual and material needs". Some of these free African-Iberians participated in the Conquest and in settler colonialism as free Iberians, and they were recognized by indigenous people as conquistadors. In Chile, the African conquistadors Juan Valiente, Juan Beltran and Juan Fernandez took part in the conquest, as well as the Catholic Juan Garrido in Mexico. Catholic values were dissemiated by the pioneer free and converted African-Iberians who arrived in America and participated in the conquest to save indigenous souls in the name of Christ (Darien, 1995).

This co-opting of some Africans in the beginning of the conquest can be seen as one of the mechanisms through which colonialism never ends the colonial relationship, but, instead, the colonizer forever subjugates the colonized groups (Veracini, 2011).

After the discovery of America, the European-African relationships changed to a new system of slavery through the trafficking of millions of enslaved Africans to the New World, a rentable commerce that continued for over three hundred years (Darien, 1995). This Western biopower strategy separated human species into groups, through a biological division of humanity in races, and imagining the inhumanity of certain foreigners - the indigenous and African. The Western economy of biopower invented races (and racism) to regulate the freedom, life and death of members of these other supposedly inferior human groups (Mbembe, 2003; Scott, 2011). 
How can the crisis of indigenous population and its replacement with enslaved Africans can be analyzed from the perspective of Western biopower strategies to eliminate and manipulate populations in settler societies? And how did the invention of races, inhumanity and inferiority of these groups operate to reproduce contemporary settler colonized societies in Latin America? And how can racism, which originated in the Western biopolitics of terror, can be understood in the present?

These questions guided the review and historical analysis in this article.

\section{Methods}

The method is based on the analysis of the historic origin, on the dynamic and evolution of indigenous and African discrimination, using literature review of the predominant concepts, discourses and scientific expressions on slavery, races and racism, their relationships with eugenics emergence in Europe and the United States and its arrival and adaptation in Latin American countries, in the period between the two world wars and up to the present day. The review focuses on the processes, policies and networks through which modern slavery, racism and eugenics were originally formed in modern Europe and the United States in the context of rapid industrialization and economic growth. However, social changes are not analyzed through the economic lens, considering mainly the development experienced in the passage to Modern-industrialized countries. Instead, the emphasis is put on the historical population changes (Lloyd, 1991), in the role of the state, the body politic, and scientific and intellectual actors in creating and promoting biopolitics through institutional and population policy changes, as well as the origins of the modern cultural background, interests, values and ideologies that led to these activities and policies being implemented in very close collaboration with international partners. International collaboration between colonizers and colonized countries is a stress point in a region moving from four centuries of colonialism and slavery to new independent republics and the continuous reproduction of racism and extreme inequalities. The historical evolution of modern slavery, racism and eugenics allows the description of the mechanisms of biopolitics which were imported from Europe and the United States since the colonial period.

\section{Results}

As a result of the massive African slave trade, in some Latin American countries there were 15 enslaved Africans to one European, and in colonial Buenos Aires, Lima and Mexico City, almost one half of the population were Africans. These proportions corresponded to the economic and labor needs in each region, including pearl fishing, mining, carpentry, sharecropping, domestic chores, and mining in Mexico, Argentina, and Chile - substantially different from the slavery in the plantation economies of the Caribbean and Brazil. Each slavery regime had abstract local codes of conduct, all of them under a state of exception, considering European laws, values and norms - societies made up of free men and women as equals. In contradiction to the legitimized European and Catholic values, Africans were treated as inhuman, as had never been seen in previous forms of slavery (Selfa, 2002; Klein \& III, 2007). The state of law was suspended in settler coloniaism and changed to a permanent state of exception for indigenous people, Africans and their descendants. The biopower mechanisms of exception included manumission to buy freedom, prohibition of inter-race marriages, rape, forced sterilization, cruelty, and even killing and extermination (Darien, 1995; Mbembe, 2003).

According to Mbembe (2003), African slavery and the plantation system are the origin of the modern state of exception and of biopolitical experimentation, where "the humanity of the slave is denied according to a triple loss: loss of a "home," loss of rights over his or her body, and loss of political status... an absolute domination, natal alienation, and social death 
(expulsion from humanity altogether), ... there may be no community, no exercise of the power of speech and thought, no reciprocity, except for rebellion and suicide, flight and silent mourning... As an instrument of labor, the slave has a price. As a property, he or she has a value... is alive but in a state of injury, in a phantom... Slave life, in many ways, is a form of death-in-life,....” (Mbembe, 2003 pp. 11).

\subsection{Modern Slavery in Europe and North-America and the Emergence of Racism.}

In the United States, until the end of the 17th century, slave labor of already operated on a large scale up to the end of the 17th century, but, until then, slavery was not related to the color of the worker, but only to the lowest cost of his labor, since the cost of bringing white servants and contracted European migrants, became much greater than the cost of trafficking Africans. The African slave trade was a large commodity business, more advantageous than the servitude of Europeans. While this economic advantage lasted, there was no rigid racial division of labor in the colonies and, until the 17th century, there were even many joint escapes and revolts by white servants and enslaved blacks, which provoked the elite's fear of a multiracial revolt (Selfa, 2002).

From the 18th century onwards, the American Revolution and the French Revolution replaced Christianity with new moral values: "all men are born free and equal." However, this ideal did not include indigenous people, blacks and women, who were the majority of the population. Slavery remained an excellent business for the economy, so the enslaved Africans should not be tempted by revolutionary freedom, even though, the trafficking and slavery of Africans in the Americas was at odds with the new modern values of freedom, equality and fraternity.

It was necessary to justify why these values, supposedly universal, should be applied only to some men and denied to others. For this, the idea of human differences was created indigenous and black slaves were considered races of sub-human beings, intellectually and morally inferior, with little intelligence and no moral values, while the white race was composed of superior men, more intelligent and with firm moral values. This division was ordained by God, who, in creating man, attributed natural supremacy to whites and natural inferiority to blacks. In addition to its divine and natural character, in modern Europe, the division of men was legitimized by modern science, which studied ethnic and phenotypic differences, and the physical traits and diverse cultures of human, in order to identify, scientifically, the true human beings and the sub-humans (intellectually and morally lower beings). Institutions and laws were created to apply such scientific criteria and classifications that would prove the supremacy of the white man. Therefore, racism is a product of modernity, of modern science, and was not observed or registered in previous civilizations (Selfa, 2002; Klein \& III, 2007).

The idea of races was widely reproduced by opinion makers in Europe and the United States by churches, universities and newspapers. Scientific papers, manuals, encyclopedias and educational materials were published to teach and popularize the concept of races and to legitimize the idea of the divine, natural and scientific inferiority of indigenous people and enslaved blacks. Hume and Thoma Jefferson reinforced these ideas during the 18th century, in order to justify the "naturalness" of black slavery in the United States. Legitimized by religion and science, the African slave trade uprooted more than 15 million people to work in the New World plantations. About 13\% of the enslaved (1.5 million) died during the ships' voyages (Selfa, 2002).

Scientific racism has made it possible to ignore the historical responsibility of human beings themselves in this tragedy and conceals a brutal historical fact - racism was invented in modern times, so that we would accept the attacks against millions of enslaved Africans as natural (Selfa, 2002). 
As a new Western biopower mechanism, racism and eugenics leads to those colonized still laboring for and continuing to be controlled by their erstwhile colonizers even after the colonial relation has been formally replaced by new independent nations and even after the abolition of slavery in new independent republics (Veracini, 2011).

\subsection{The Spread and Legitimizing of Eugenics}

In 1863 , the formal scientific theory of the upper and lower races - eugenics, was created by Francis Galton. This pseudoscience claimed that the upper classes in Britain assumed better social positions because they had a superior genetic makeup, which should be adopted as a model for the human species, since modern man was already capable of directing his evolution himself through science, seeking to "improve the innate qualities of a race to the maximum advantage". The mechanisms for this "creative selection" included the selection of people with genetic superiority (Nordic and Saxon) and the prevention of miscegenation, through immigration control and the forced sterilization of the poor, disabled, malformed, mentally ill, migrants, black people and other groups who were considered immoral or undesirable, and who should therefore be gradually eliminated from society. The characteristics considered "incompatible with life" were present in the "bad species" and would impoverish the racial qualities of a population and its future generations. For this reason, societies should "leave out the moral discussion" and assume that "it is better to be healthy than sick, vigorous than weak, well-equipped than ill-equipped".

Therefore, each social class or sect should be represented by its best examples, and society should "let them work for their common civilization in their own way". Desirable special skills would be "assessed by those who possess them: artistic faculties assessed by artists, the ability for inquiry and veracity would be assessed by scientists, the capacity for religious absorption by mystics, and so on." These would be the members and representatives of a community, men better than their constituent bodies, because they would have more of the qualities needed by the state - more vigor, more capacity and greater consistency of purpose. Thus, the community could be "confident of refusing criminal representatives and those defined as undesirable, chosen legitimately by the best examples of its class, according to health, energy, skill, virility, and courteous disposition". (Galton, 1904).

"Large and prosperous families are more often the source of Eugenia's conditions. The definition of a prosperous family is one in which children have clearly gained levels above the positions reached by their peers early in life. Families considered "large" contain, at least three adult male children." (Galton, 1904)

In 1908, in London, the Eugenics Society was founded, which promoted policies of "hygiene or social prophylaxis", with the aim of preventing the procreation of people with hereditary diseases and of eliminating those with physical or mental problems (Goldim, 2003).

In 1912 the First International Eugenics Congress was held in London with 750 participants from several European countries as well as from the United States (Stepan, 1996).

In 1924 the International Commission of Eugenics published a report written by fifteen full members: Argentina, Belgium, Cuba, Czechoslovakia, Denmark, France, Germany, Great Britain, Italy, Netherlands, Norway, Russia, Sweden, Switzerland, and the United States. In addition, seven other countries were eligible for cooperation - Brazil, Canada, Colombia, Mexico, Venezuela, Australia, and New Zealand (Adams, 1990).

By 1930, eugenics had been accepted by thirty countries with diverse Galtonian approaches, under local scientific, cultural, institutional, and political conditions, and developed by biologists, animal breeders, physicians, pediatricians, psychiatrists, anthropologists, demographers, and public health officials, adopting two methodologies - predominantly 
Lamarckian (inheritance of acquired characteristics and hygiene approach) or, alternatively, Mendelian (biological determinism) (Bowler 1984; Adams, 1990).

Most educated whites in Europe and North America accepted the racial and cultural superiority of Caucasians, a different approach when compared to the ideologies of Aryan or Nordic supremacy adopted later by the Aryan-minded eugenicists during Hitler's dominant period, but this was rejected by some eugenicists. All the regions of the world were influenced by Western science, medicine, values and ideas, and Latin America is considered to have been the "mainline" of eugenics movements, contributing to their development (Stepan, 1996).

The movement from traditional imperialism to modern slavery and, finally, eugenics, follows a logical sequence of diverse biopolitical mechanisms to control and extinguish the colonized population groups, benefiting the colonizers, while colonialism changes to settler colonialism in Latin America. In the new independent republics, as settler societies, although the indigenous and Africans are formally recognized as free groups, they continue to be considered sub-human by racists and supporters of eugenics, as biopower means to continue dominating, subsuming, neutralizing and extinguishing the alterities of colonized groups, The active repression of colonial biopolitics shifted to settler politics in new independent republics, with incorporation by recognition, while strengthening the control and submission through racism and eugenics (Veracini, 2011).

\subsection{German and Italy Eugenics and Fascism}

Between 1890 and 1903 eugenics emerged in Germany and Italy as an ideological perspective of the defense of the Nordic race and Aryan supremacy, based on the Darwinist ideology in order to improve the human race. The contexts of social crisis, rapid industrialization, intellectual and medical development were the background that explain the German eugenics even during the Wilhelmine and Weimar political period — the promotion of a healthier, more productive and powerful nation through race hygiene. Almost all German intellectuals were race hygienists with a technocratic and rational logic applied to managing the population through strategies of race hygiene and hereditary fitness in order to prevent a cultural, economic, and political German decline and to promote the survival of Germany and Western Europe's superior cultural traditions (Adams, 1990).

It was only between the two world wars, after Hitler's rise to power, that political diversities in eugenics were eliminated, being disseminated all over the world through international organizations and pressure groups, in connection with other themes of modern times nationalism, racism, sexuality and gender, social hygiene, and modern genetics in Europe and the United States (Stepan, 1996).

The "positive Eugenic policies" were legitimized. In 1933 the Sterilization Act was approved in Nazi Germany, followed by the prohibition of marriages; and "negative Eugenic policies" such as the extermination program aimed to decrease the number of individuals classifieas "degenerated" (Weiss, 1986).

In Italy, fascism sought to "root out the unhappy unions and the inferior race not inheriting Ancient Rome (including from the Ethiopia colony). Fascism did not value the biological race as much as Nazism, but adopted the spiritual and historical-linguistic sense of recovery of the prestige of the Ancient Rome, the defense of preciousness, and the unity and the Aryan type.

According to Mbembe (2003), the biopolitics of cruelty in plantation system and the apartheid regime, as well as racism and eugenics are the origin of a peculiar terror formation, articulated to biopower, the state of exception, and the state of siege. 


\subsection{Eugenics in the United States, its recognition as science, and its application as National Policy}

In the United States, the eugenic movement received generous funding from institutions such as the Carnegie Institution, Rockefeller Foundation, Harriman Railway and the Race Betterment Foundation. In 1906, the American Breeder's Association (ABA) was created, with the aim of "investigating and reporting on heredity in the human race, emphasizing the value of higher blood and the threat to lower blood society." In 1910, a wide network of scientists, reformers and professionals was formed to promote eugenic legislation and in 1911, in New York, the Eugenic Data Workshop, ERRO, was founded by Charles B. Davenport, which collected information from families with pedigrees and identified those that were inappropriate, of poor origin, black and sick. For these, considered "unfit" or "genetically defective", it was proposed to remove them from society, through sterilization, marriage restrictions and emigration. This cleansing was defined as "selective breeding of high quality individuals". In 1928, eugenics was an official discipline offered in 376 university courses at major schools in the United States, with more than 20,000 students. Critics of eugenics as a scientific method, like Thomas Hunt Morgan, were rare. (Kimmelman, 2007; Kuhl, 2002)

With great public acceptance, US eugenic legislation was passed. As of 1896, 27 states enacted laws with eugenic criteria. In 1897, a compulsory sterilization law was suggested, but not passed by the Michigan parliament. In 1905, the parliament of Pennsylvania passed a sterilization bill, but it was vetoed by the governor. In 1907, Indiana was the first state to enact the sterilization law, and was followed by Washington and California in 1909. California completed a record 20,000 sterilizations, out of the 60,000 performed in the country until the 1960s. Eugenics of North Carolina promoted and implemented the sterilization of thousands of people between 1933 and 1977, who, after being evaluated by social workers, were given an Intelligence Coefficient (IQ) below 70. This was considered a preventive method of unwanted pregnancy, and was cheap and practical. The poor and black people, with a low level of education, were most affected by mass sterilization as a result of tests that indicated their low IQ. Most of the sterilized people were women, many classified as "bad girls", "in love" or "ultra-sexualized" (Kuhl, 2002; Black, 2003).

Immigration laws and restrictions, proposed by scientists trained at Harvard University, have also worked since 1894 to prevent the entry of inferior races into the United States of America, since they considered that sexual involvement with less developed and civilized races was a biological threat to the North American population, as it would "dilute the upper American racial stock", that of the upper Anglo-Saxon class in the north of the country (Kuhl, 2002)

In 1902, the president of Stanford University created the notion of "blood race" in the document "Blood of a Nation" declaring that talent passed through blood as human qualities. In 1904, the Carnegie Institution established a laboratory with millions of racial index cards for Americans' families, lineages and entire populations. The Harriman Railway financed New York charities, the Bureau of Industries and Immigration, to look for Jewish, Italian and other immigrants for their deportation, confinement or forced sterilization, as the desirable species to populate America included only strong people and talented, blond and blue-eyed Nordic types, the only ones "apt to inherit the land". Thus, the American eugenic movement worked to remove the freed blacks, the immigrant Asian workers, the indigenous indians, Hispanics, Eastern Europeans, Jews - all of them with dark hair - and the poor and sick from the genetic line of the country, eliminating their lineages and descendants, by extinguishing the reproductive capacity of those considered weak and inferior (Kuhl, 2002; Black, 2003; Cohen, 2016).

In 1911, economist Frank Taussig, from Harvard University, published his book "Principles of Economics", in which he proposed the sterilization of unworthy individuals, with a special focus on the poorest, saying... 
"The human race could be vastly improved in quality, and its ability for a happy life, if those with bad physical and mental gifts could be prevented from multiplying", and "Certain types of criminals and poor people only generate people of their own kind, and society has the right and the duty to protect its members of the permanent maintenance and guard load of these parasites." (Taussing, 1911, as cited in Cohen, 2016).

In 1918, a specialist in venereal diseases published the textbook "Eugenia Aplicada", and one of the chapters was entitled "Lethal Selection", stating that...

"...from a historical point of view, the first method presented is execution ... its value in maintaining the breed standard should not be underestimated... through the destruction of the subject by some negative characteristic of the environment, such as excessive cold or bacteria, or due to physical disability. " (Popenoe, 1918, as cited in Black, 2003).

Although the most suggested method of eugenic homicide in America was a "lethal chamber", or gas chambers operated in public places, it was believed that society was not prepared for an organized lethal solution. Thus, many eugenic institutions and doctors started to practice eugenic lethality on their own initiative, for example, by offering milk from tuberculous infected cows to patients, neglecting the care of newborns or applying more aggressive methods to mental patients, in addition to forced segregation, sterilization and restrictions on marriage (Black, 2003; Cohen, 2016).

In 1927 the United States Supreme Court legitimized methods of eugenics saying "It is better for everyone if, instead of waiting to execute degenerate descendants for crime, or to let them starve for their imbecility, society can prevent those who are manifestly unfit to continue to exist .... Three generations of imbeciles are enough." (Minister Oliver Wendell Holmes, STF, quoted in Black, 2003 and Cohen, 2002)

Despite the historical record that eugenics was created by Galton, it had appeared earlier in the United States, where it had already become popular.

Hitler studied US eugenic laws, and his racial hatred program, starting in 1924, acquired scientific legitimacy in the American intellectual and academic milieu, which established deep relations with Nazism, and advised and financed professional fascist eugenic experiences in Germany.

"I have been studying with great interest the laws of several American states regarding the prevention of reproduction by people whose offspring would, in all probability, be of no value or harmful to racial stock." (Hitler, as cited in Cohen, 2016)

The Rockefeller Foundation helped found the German eugenics program by funding Josef Mengele's program before his trip to Auschwitz, with a donation of about USD 410,000 in 1926 and the Institute for Brain Research donated USD 317,000 to the Kaiser Wilhelm Institute to spend on the stage of the biology of the German race, led by Ernst Rudin, whose organization implemented murderous experiments through research on Jews, Gypsies and other groups (Black, 2003; Cohen, 2016).

Anglo-American eugenics was largely private and supported by philanthropy, whereas German race hygiene evolved within a statist medical tradition. (Adams, 1990)

From 1940 onwards, it is estimated that between 50 and 100 thousand elderly and mentally ill Germans were deinstitutionalized and taken to the gas chambers (Cohen, 2016). That is the historic reasons why, years later, at the Nuremberg trials, the Nazis cited American scientists in their own defense (Black, 2003; Cohen, 2016).

In 1948, in response to these crimes against humanity - including eugenic practices - the countries of the international community, at a meeting at the UN, adopted the Universal Declaration of Human Rights, recognizing among their principles that we are all part of a single human race. 
"All human beings are born free and equal in dignity and rights. They are endowed with reason and conscience and must act with others in a spirit of brotherhood. "

Recently, the Third World Conference Against Racism, Racial Discrimination, Xenophobia and Related Intolerances, held in 2001 in Durban, South Africa, during the presidency of Nelson Mandela, resulted in a Declaration and Plan of Action expressing the commitment of States in the fight against discrimination and racism, which persists until today and considering slavery and racism as crimes against humanity...

"Currently, countries that participate in the UN recognize that slavery, the sale and trafficking of enslaved people were atrocious tragedies in our history, they were true crimes against humanity, organized barbarism against millions of people, which denies the humanity of the victims." (OHCHR and UNESCO, 2001).

\section{Discussion}

\section{Racism and Eugenics in Latin America: Cosmic Miscegenation or Latin Superiority?}

American conquest and colonization extinguished most indigenous groups by wars, epidemics and a set of biopolitical mechanisms adopted simultaneously, alternating genocide and amalgamation of indigenous groups. The participation of some free Africans in the conquest was paramount, and rapidly substituted by massive modern African trafficking and slavery, to replace the indigenous workforce, particularly in plantations, as in the case of Brazil and the Caribbean, and in other productive sectors of agriculture and mines, under inhuman work conditions and cruel punishments. Scott (2011) affirms that "Slavery also produced a centurieslong genocidal catastrophe by commodifying African people not for survivability but exchangeability". This combined set of biopolitical mechanisms eliminated indigenous nations and, at the same time, enslaved and killed millions of Africans. Both mechanisms of colonial biopolitics coninued to be reproduced, through the modern invention of races, racism and eugenics, which continued eliminating and amalgamating both colonized groups, progressively substituted by free European immigrants, in order to whiten settler colonized populations.

In Latin America, in the first decades of the $20^{\text {th }}$ Century, Italian and French academic and scientific eugenicists were pioneers in disseminating Lamarckism, puericulture, and French concerns about the prospect of underpopulation.

Later, the USA promoted and financed the Anglo-German eugenics perspective and projects in Latin America and the Caribbean, and even sent Harvard professors to organize curricular reforms in the universities, particularly in Law and Medicine. However, while in the USA academics and government advocated for racist eugenicism, Latin American elites, mostly miscigenated, adapted Eugenics to develop a new construct of miscigenation, represented as being of high value and a way of showing their appreciation of the Latin American race.

Therefore, racism and eugenics continued the logic of elimination of indigenous and African peoples, representing the biopolitics of settler colonialism, which "arose in the Americas by perpetuating African diasporic subjugation and Indigenous elimination simultaneously". (Scott, 2011).

Eugenics brought new conflicts and traumas to the Latin American identity and gained strength at the moment of the formation of nation-states and national identities.

Eugenic societies were created in Buenos Aires in the 1930s, inspired by Italian fascism, with the objective to "create a national racial archive for matrimonial selection and (compulsory) sex education".

After exterminating indigenous people and making African descendents almost invisible through European immigration, Argentinians lived through a moment of crisis and a predominance of the extreme right and xenophobia. Argentina was the only country in the 
region that achieved the desirable racial whitening $-50 \%$ of the population could be traced back to Italian migrants, and fascism was legitimated in the ideal of the "difesa della stirpe", opposition to abortion, and the defense of breed reproduction for the European descendants.

Eugenics movements were extended into the whole region and shaped science, social thought, and policies primarily between the two world wars, through congresses and social legislation on child welfare, maternal health, family law, the control of infectious diseases, and immigration, as well as establishing some of the first courses on genetics in the region, including the Pan American conferences between 1900 and 1940. The International Latin Federation of Eugenics Societies was founded in 1935 by Corrado Gini, president of the Italian Society of Genetics and Eugenics. Eugenics societies from Italy, France, Romania, Mexico, Peru, Catalonia, Brazil, and Belgium and delegates from other 20 Latin American countries participated in an international meeting in Mexico City. In 1937 the International Federation held its first and only congress in Paris (Adams, 1990).

Medical-legal debates and legislative activities promoted the state in regulating marriage, according to the Lamarckian approach, influenced by France and Italy, but also adopted the "Anglo-Saxon" type.

For example, Mexico started the $20^{\text {th }}$ Century as a Secular State, after the popular Revolution of 1910. The new laic and revolutionary State faced the Catholic obstacles experienced by other Latin American countries. Mexico adopted the Vasconcellos's vision of a superior mestizo or "cosmic" race, born out of the fusion of Caucasian, Indian, and African peoples, and an unofficial, real marginalization of the Indian and non-acculturated mestizo. However, Mexico was the only country in the region to adopt national health and sterilization policies and, since 1932, children have continuously received sex education at school (Adams, 1990).

In the early twentieth century, Argentina received a large-scale European immigration and the indigenous were exterminated. In Cuba, eugenics ideology and policies were copied from the United States.

Brazil was the first Latin American country to have a significant, organized eugenics movement. Between 1900 and 1940, Brazil experienced profound social and political changes caused by the dependent industrialization, urbanization, and massive European immigration (Adams, 1990). The French and Italian collaboration was relevant to eugenic dissemination in Brazil. Many Brazilian physicians, lawyers and scientists participated in developing a Lamarckian movement and increased the effects of the special racial and political situation (Goldim, 2003; Diwan, 2015).

Millions of indigenous peoples were eliminated and escaped from slavery. Between the 15th and 19th centuries, they were substituted by around six million Africans trafficked and enslaved in Brazil to work on sugar plantations. And finally, the modern eugenic policy of immigration substituted the Africans in the new labor market by millions European peasants (Carvalho, 2015; Adams, 1990).

At the time, in Europe, theories of racial inferiority of indigenous peoples and Africans predominated, which was the model to import and promote their comparison with animals and their enslavement in Latin America.

Although Latin American eugenics movements differed individually from one another, they seem at the same time to have shared a number of common features, mainly the eugenics approach shared with France and Italy.

\section{Conclusions}

In Latin America, modern slavery was the economic and cultural base of the colonial regimes, which continued discriminating against indigenous peoples and Afro-descendants through the 
new republics in the process of industrialization, mainly adopting the modern eugenics and racism as mechanisms to reproduce privileges of the white elites and European immigrants, while legitimizing the biological, cultural and moral elimination, genocide and amalgamation of the majority of the population in settler societies. Argentina, Brazil, Colombia and Mexico participated actively and developed new versions of eugenics, since the majority of their populations were neither Aryan nor white. This adaptation of the biopolitics of racism and eugenics to the Latin American context by elites was a mechanism with which to legitimize and, at the same time, mask racism and inequalities, in order to maintain inequalities in settler societies and to rewrite the history of the continuity and interrelation between slavery, racism and eugenics, as combined biopolitical mechanisms.

The main Latin American contribution to eugenics was, contradictorily, that underdeveloped countries, with all the elements considered inferior by eugenics - largely Catholic, rural, racially mixed, and illiterate populations, with a tropical climate and racially mixed people represented a contribution from the elites who were of European descent aiming to improve their own miscegenation, as part of a new nationalism, based on a desire to project the new independent countries into world affairs, to define and manage the latino population in latino elite terms, and to take advantage of racism and eugenics to manage the internal context of inequalities, over-exploitation and social conflicts in the promotion of European migration, the whitening of populations, and the continued submission of the majority - the indigenous and Afro-descendants, with no concessions in terms of welfare, as occurred in Europe.

This is the basic definition of the state of exception, in which racism and eugenics legitimized the racialised and colonised statuses of Latin American populations from the body of Europe - the white elites' superiority versus the non-white inferiority and submission of the majority - the miscegenated and assimilated indigenous and Afro-descendants in settler societies.

In brief, eugenics was the key biopolitical mechanism to closing the history of slavery, racism and inequalities within the region by the creation of a eugenic version of scientific racism in order to control the majority of the "degenerated" population, and to benefit exclusively the inner group of privileged elite and white immigrants enabling them to maintain the control and the status quo. In Latin America, "science and social ideologies became linked in culturally and historically specific ways that need to be examined in context" (Adams, 1990).

These are the biopolitics through which late modern colonial occupation acts precisely and continuously as settler colonizer in current societies.

\section{References}

Adams, M. B. (1990). The Wellborn Sciences. Eugenics in Germany, France, Brazil and Russia. New York, USA: Oxford University Press.

Black, E. (2003). The Horrifying American Roots of Nazi Eugenics. Retreived in https://historynewsnetwork.org/article/1796

Bowler, P. J. The role of the history of science in the understanding of Social Darwinism and Eugenics. Historical Perspectives on Science, part 1. Impact of Science on Society 40.3 pp: 273-79.

Brown, R. (1995). Prejudice: its Social Psychology. Oxford, U.K.: Blackwell Publishers.

Carvalho, J. M. (2004). Os bestializados, - O Rio de Janeiro e a República que não foi. Companhia Das Letras, 2004

Cohen, A. S. (Apr 2016). "Harvard's Eugenics Era. When academics embraced scientific racism, immigration restrictions, and the suppression of "the unfit"". Harvard Magazine. Retreived in https://www.harvardmagazine.com/2016/03/harvards-eugenics-era 
Darien, J. D. (1995). Slavery and Beyond. The African lmpact on Latin America and the Caribbean. Number 5. Washington DC, USA: Jaguar Books on Latin America.

Diwan, P. (2015). Raça Pura, A history of eugenics in Brazil and in the world. Sao Paulo: Brazil. Contexto.

Galton, F. (1994). "Eugenics: Its Definition, Scopep and Aims". The American Journal Sociology. Volume X; July, 1904; Number 1.

Goldim, J. R. (2003). “Eugenia”. Psicologia Brasil, São Paulo, , v.1, pp. 10-11.

Klein, H. S. and III, B. V. (2007). African Slavery in Latin America and the Caribbean (2nd ed.). New York, USA: Oxford University Press.

Kimmelman, B. A. (2007). "The American Breeders' Association: Genetics and Eugenics in an Agricultural Context”. 1903-13. Social Studies of Science 37. Pp. 281-296

Kuhl, S. (2002). The Nazi Connection: Eugenics, American Racism, and German National Socialism. New York, USA: Oxford University Press.

Livi-Bacci M.. (2006). "The Depopulation of Hispanic America after the Conquest". Population and Development Review 32(2). Pp. 199-232.

Lloyd, C. (1991). "The Methodologies of Social History: A Critical Survey and Defense of Structurism". History and Theory. Vol. 30, No. 2, pp. 180-219 Wiley and Wesleyan University

Mbembe A. (2003). Necropolitics. Public Culture. 15(1): 11-40. Duke University.

OHCHR and UNESCO (2001). III Conferência Mundial Contra o Racismo, Discriminação Racial, Xenofobia e Intolerâncias Correlatas, Durban.

Scott L.M. (2011) The Biopolitics of Settler Colonialism: Right Here, Right Now, Settler Colonial Studies, 1:1, 52-76, DOI: 10.1080/2201473X.2011.10648801

Selfa, L. (2002) "Slavery and the origins of racism". International Socialist Review Issue 26. Retrived from https://isreview.org/issues/26/roots_of_racism.shtml

Stepan N. L. (1996) The Hour of Eugenics: Race, Gender, and Nation in Latin America. Ithaca and Lodon, U.K: Cornell University Press.

Soares, E. (2010). "Abolição da escravatura e principio da igualdade no pensamento constitucional brasileiro (Reflexos na legislação do Trabalho doméstico)". Revista do Ministério Público do Trabalho n. 39, Ano XX, São Paulo: Brasil. Ed. LTr.

Vala J., Brito R. and Lopes D. (1999). Expressões dos Racismos em Portugal. Lisbon, Portugal: Imprensa de Ciencias Sociais.

Veracini L. (2011) Introducing, Settler Colonial Studies, 1:1, 1-12, DOI:

10.1080/2201473X.2011.10648799

Weiss, S.F. (1986). "Wilhelm Schallmayer and the Logic of German Eugenics". ISIS. Vol.77, N.1. PP. 33-46. University of Chicago Press. 